\title{
Real-World Vehicle Volatile Organic Compound Emissions and Their Source Profile in Chengdu Based on a Roadside and Tunnel Study
}

\author{
Miao Feng ${ }^{1,2, * \mathbb{C}}$, Xiang Hu ${ }^{2}$, Li Zhou ${ }^{1}{ }^{\mathbb{D}}$, Tianyue Zhang ${ }^{2}$, Xiao Zhang ${ }^{2}$, Qinwen Tan ${ }^{2}$, Zihang Zhou ${ }^{2}$, Ye Deng ${ }^{2}$, \\ Danlin Song ${ }^{2}$ and Chengmin Huang $1, * \mathbb{D}$ \\ 1 College of Architecture and Environment, Sichuan University, Chengdu 610065, China; lizhou@scu.edu.cn \\ 2 Office of Atmospheric Environment, Chengdu Academy of Environmental Sciences, Chengdu 610072, China; \\ hux@cdaes.org.cn (X.H.); zhangty@cdaes.org.cn (T.Z.); zhangxiao@cdaes.org.cn (X.Z.); \\ tanqw@cdaes.org.cn (Q.T.); gorezhou@gmail.com (Z.Z.); dengye@cdaes.org.cn (Y.D.); \\ songdl@cdaes.org.cn (D.S.) \\ * $\quad$ Correspondence: fengm@cdaes.org.cn (M.F.); huangcm@scu.edu.cn (C.H.); Tel.: +86-183-2830-6381 (M.F.)
}

\section{check for} updates

Citation: Feng, M.; Hu, X.; Zhou, L.; Zhang, T.; Zhang, X.; Tan, Q.; Zhou, Z.; Deng, Y.; Song, D.; Huang, C. Real-World Vehicle Volatile Organic Compound Emissions and Their Source Profile in Chengdu Based on a Roadside and Tunnel Study. Atmosphere 2021, 12, 861. https:// doi.org/10.3390/atmos12070861

Academic Editors: Artur Badyda and Chris G. Tzanis

Received: 29 May 2021

Accepted: 29 June 2021

Published: 2 July 2021

Publisher's Note: MDPI stays neutral with regard to jurisdictional claims in published maps and institutional affiliations.

Copyright: (c) 2021 by the authors. Licensee MDPI, Basel, Switzerland. This article is an open access article distributed under the terms and conditions of the Creative Commons Attribution (CC BY) license (https:/ / creativecommons.org/licenses/by/ $4.0 /)$.
Abstract: With the continuous progress of air pollution prevention and control in China, the study of the emission characteristics of vehicles has become increasingly important. An in situ experiment was performed in the Tianfu tunnel in Chengdu to determine the vehicle emissions of volatile organic compounds (VOCs). A total of 50 species of VOCs were quantified in the tunnel, with total concentrations in the range of 32.25-162.18 ppbv in the entrance and 52.90-233.92 ppbv in the exit, respectively. Alkanes were the most abundant group, followed by alkenes, aromatic hydrocarbons, oxygenated VOCs, alkynes and chlorocarbons. The general emission factors of the measured VOCs ranged from $141.71 \mathrm{mg} \mathrm{veh} \mathrm{km}^{-1}$ to $236.12 \mathrm{mg} \mathrm{veh}^{-1} \mathrm{~km}^{-1}$, and the average \pm std was $177.31 \pm 24.59 \mathrm{mg} \mathrm{veh}^{-1} \mathrm{~km}^{-1}$. The emission factors of diesel-fuelled vehicles, gasoline-fuelled vehicles and natural gas-fuelled vehicles were estimated based on linear regression analysis, with values of $272.39 \pm 191.17 \mathrm{mg} \mathrm{veh}^{-1} \mathrm{~km}^{-1}, 185.08 \pm 12.85 \mathrm{mg} \mathrm{veh}^{-1} \mathrm{~km}^{-1}$ and $158.72 \pm 3.21 \mathrm{mg} \mathrm{veh}^{-1} \mathrm{~km}^{-1}$, respectively. The results of roadside experiments indicate that the roadside ambience atmosphere contains many species characterized with vehicle emission features. Especially, there were fuel evaporation emission related substances, which were higher in content than tunnel samples.

Keywords: volatile organic compounds; tunnel experiment; vehicular emissions; emission factors; roadside sampling

\section{Introduction}

With the rapid growth of China's economy and urbanization, air pollution in China presents regional and heterogeneous characteristics with the coexistence of primary and secondary pollutants [1-3]. The high emission of a variety of pollutants leads to the coexistence of primary and secondary pollution. In addition, with transport and transformation processes in a large area, a series of atmospheric composite pollution phenomena are caused. In recent years, urban air quality has improved significantly, and particulate matter (PM) concentration has dropped rapidly due to the implementation of the clean air action plan [4]. However, atmospheric pollutants have not been eradicated, in particular, ozone $\left(\mathrm{O}_{3}\right)$ concentrations have shown an increasing trend in recent years, and the photochemical pollution potential has not been effectively curbed. Volatile organic compounds (VOCs) are an important precursor of photochemical smog [4-7], which is emitted from either natural or anthropogenic sources [8-10]. In the urban environment, vehicle exhaust is becoming a significant source of VOCs. Its contribution ranges from $34 \%$ to $45 \%$ among the major cities of China [11,12]. The types and quantities of VOCs emitted by vehicles vary greatly, depending on the type of vehicle fuel, the type of motor vehicle, the driving conditions, the 
condition of the vehicle, the driving environment and meteorological factors (temperature and pressure) [13-16]. The different reactivity of VOCs also leads to different contributions to photochemical smog. Therefore, obtaining a reliable mobile source emission profile and emission factors (EFs) is a way of assessing accurate vehicle emission impacts and identifying mitigation strategies for photochemical smog.

There are a series of studies analyzing on-road emissions [17-22]; some of them focus on different vehicle emission equipment, and others concern characteristics of regional vehicle emission. Others concern regional vehicle emission characteristics which were conducted in China, especially Beijing-Tianjin-Hebei, Yangtze River Delta and Pearl River Delta regions [23-25], yet little attention is paid to the southwest.

Chengdu, a mega city in southwest China, has the second-highest number of cars in China (45.2 million) [26] and suffers ozone pollution accordingly [27]. To provide insight into vehicle VOCs emissions in Chengdu, a pilot study was carried out in the heavily used Tianfu tunnel in 2017. The aim was to set up a preliminary VOCs profile and EFs of vehicle emissions in urban Chengdu, and assess the influence of vehicle emissions on ambient air. The output of the research will be useful for establishing a local VOC emission inventory and optimizing related policy evaluation models. In addition, it will provide important information for traffic pollution management in mega-cities.

\section{Methodology}

\subsection{Sampling Sites}

The Tianfu tunnel (TFT) $\left(33.064^{\circ} \mathrm{N}, 104.073^{\circ} \mathrm{E}\right)$ is a twin-bore tunnel in the centre of Chengdu (Figure 1). The two bores are a west-to-east passage and east-to-west passage that are separated by a solid wall, and each bore has two lanes (without walkways). The tunnel measurements were conducted in the west-to-east passage. Two sample sites were set up at the roadsides, 300 metres away from the entrance and the exit of the passage (Figure 2). These two sample sites were named TFT-A and TFT-B. The cross-sectional area of the west-to-east passage is $50.0 \mathrm{~m}^{2}$, and the designed speed of the tunnel is $60 \mathrm{~km} / \mathrm{h}$, while the average speeds of vehicles range from 40 to $60 \mathrm{~km} / \mathrm{h}$. There are four exhaust-air fans installed along the ceiling throughout the passage. These fans turn on twice a day, from 9:00 to 10:00 and 18:00 to 19:00 local standard time [LST]. Therefore, at times beyond these two periods, fresh air supply throughout the bores is limited, and the only air movement is that induced by the piston effect of vehicle movement; these conditions mean that the air pollutant dilution factor could be eliminated. The wind speed was monitored by a sensor suspended on a tripod close to the side wall of sample site B at a height of two meters. Cameras were used to film the traffic flow at TFT-B, and the number and types of vehicles that passed through the tunnel were effectively recorded.

To further analyse the influence of vehicle emissions in the open environment, samples of roadside ambient air were collected in this study in addition to the tunnel experiment. Considering that driving speed and traffic flow affect the road vehicle emission strength in the same small meteorological environment, roads with three different levels of use were chosen for sampling, namely, a main road, a branch road and an expressway. The main road is Renmin South Road (RSR) (Figure 1), the busiest road in Chengdu, with a north-south direction. The main road of RSR is six lanes in both directions, with a designated speed of $70 \mathrm{~km} / \mathrm{h}$, which are separated from an auxiliary road lane with a designated speed of $40 \mathrm{~km} / \mathrm{h}$ by $2-\mathrm{m}$-wide green belts (containing only grass and miniature ornamentals). The sample location was set at a section without traffic lights or side roads. Two sampling points on RSR were set on the green belt on both sides of the road, where the sampling tanks were suspended $2 \mathrm{~m}$ above the ground on a tripod. The secondary road samples were taken at Fanglin Road (FLR). FLR is a two-way, two-lane road with a total length of $800 \mathrm{~m}$ and a designated speed of $40 \mathrm{~km} / \mathrm{km}$, linking the city's main roads, the First Ring Road and Dashi Road. The samples were taken from both sides of the road in the middle section. The intercity expressway samples were collected at Hongguang Avenue (HGA), which is a two-way, ten-lane road with a designated speed of $80 \mathrm{~km} / \mathrm{h}$. HGA is the main 
road linking the southwestern suburban regions with downtown. The sample location was set at a section without traffic lights or side roads within $400 \mathrm{~m}$. The sampling points were set on the roadsides, where the sampling tanks were suspended $2 \mathrm{~m}$ above the ground on a tripod.

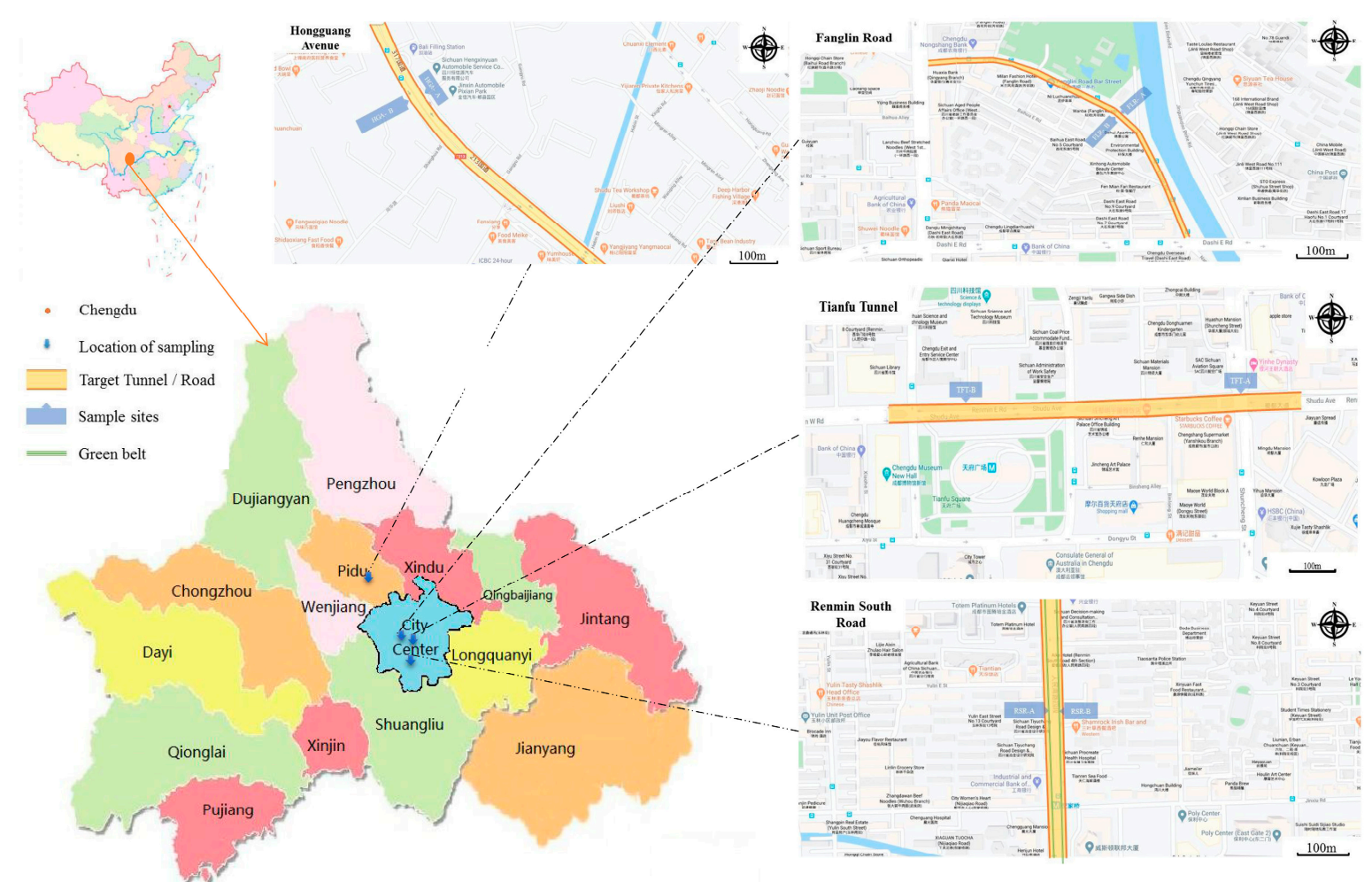

Figure 1. Sampling sites at Tianfu Tunnel and three roads. Renmin South Road (RSR) represents main roads, Fanglin Road (FLR) represents branch roads and Hongguang Avenue (HGA) represents expressways.

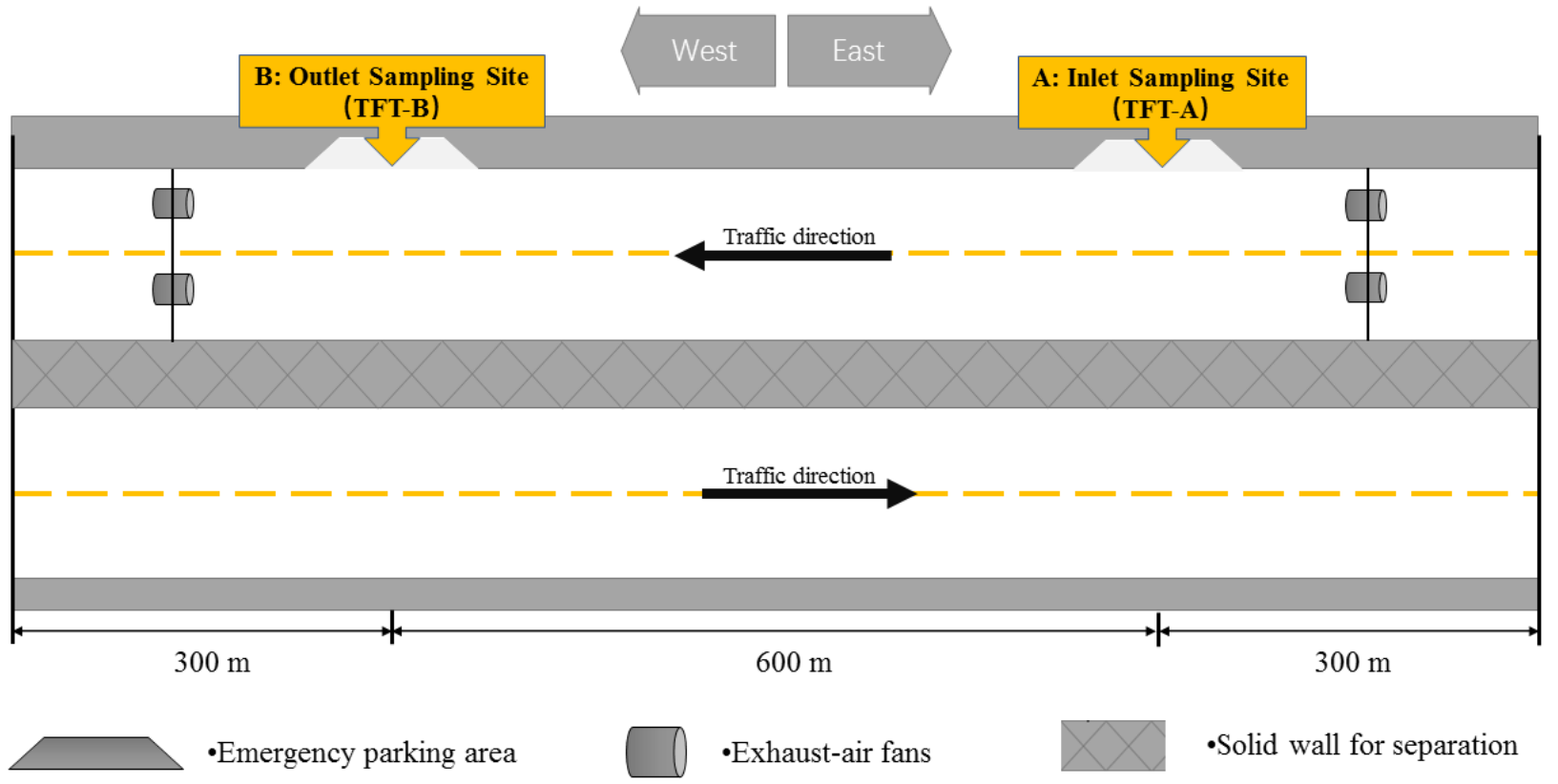

Figure 2. Schematic diagram of sampling sites (A and B) in the Tianfu tunnel (TFT). 


\subsection{Sampling and Analysis}

The experiments were conducted on four days during July and August 2017, from early morning to late evening (8:00-20:00). Considering the traffic flow differences among the sampling sites and the analytical budget, the time interval of sampling differed among the sampling sites. As listed in Table 1, the sampling interval for FLR and HGA was two hours, and that for RSR and TFT was one hour. Road environment samples were taken at both sides of the road at the same time to reduce the sampling error caused by uneven vehicle flow.

Table 1. Sampling time and frequency at the sampling sites.

\begin{tabular}{cccccc}
\hline Date & Time & Sampling Sites & Frequency & NO. of VOC Samples & NO. of NO $_{2}$ Samples \\
\hline 18 July & $8: 00-20: 00$ & FLR & $2 \mathrm{~h} /$ sample & 12 & 6 \\
21 July & $8: 00-20: 00$ & RSR & $1 \mathrm{~h} /$ sample & 24 & 23 \\
3 August & $8: 00-20: 00$ & HGA & $2 \mathrm{~h} /$ sample & 12 & 23 \\
15 August & $8: 00-20: 00$ & TFT & $1 \mathrm{~h} /$ sample & 24 & 20 \\
\hline
\end{tabular}

A total of 72 air samples were collected for VOC analysis. The samples were collected in pre-cleaned and pre-evacuated 2 L SUMMA stainless steel canisters with a flow control valve, which controlled the air sample flow rate at $33.4 \mathrm{~mL} / \mathrm{min}$. The stainless-steel canisters were pre-treated using USEPA method TO-15. To prevent decreases in sample activity and species, after daily sampling, the samples were immediately sent to the analytical laboratory at SGS-CSTC Standards Technical Services Co., Ltd. (Shanghai, China), and the laboratory analysis was completed within one week. A total of 108 target species, including 30 alkanes, 11 alkenes, 17 aromatic hydrocarbons, 1 alkyne, 35 chlorocarbons and 14 oxygenated volatile organic compounds (OVOCs), which are listed in Table S1, were analysed based on the methods of USEPA TO-15 [28] and HJ 759-2015 [29], with a detection limit of $0.66-0.78 \mathrm{ppbv}$ for individual species.

Ambient air $\mathrm{NO}_{2}$ samples were collected by a porous glass absorption tube through a medium-flow sampler with a sampling flow of $0.1 \mathrm{~m}^{3} / \mathrm{min}$ and a sampling time of one hour. The samples were analysed immediately after daily sampling based on the aniline- $N$-(1-naphthyl) ethylene diamine dihydrochloride spectrophotometric method for air quality determination (GB/T 15,502 1995) [30]. In total, $72 \mathrm{NO}_{2}$ samples were collected; the detailed sample collection information is provided in Table 1.

\subsection{Emission Factor Calculations}

The vehicular EF calculated based on tunnel research reflects the fleet-average EF from mixed types of vehicles during the monitoring period. The EF (in mg veh ${ }^{-1} \mathrm{~km}^{-1}$ ) is the mass of pollutants emitted over a certain distance normalized by the vehicle number and distance $[19,31]$.

$$
\mathrm{EF}_{\mathrm{veh}}=\frac{\left(\mathrm{C}_{\text {outlet }}-\mathrm{C}_{\text {inlet }}\right) \times \mathrm{A} \times \mathrm{U} \times \mathrm{t}}{\mathrm{N} \times \mathrm{L}}
$$

where $\mathrm{EF}_{\mathrm{veh}}$ is the average $\mathrm{EF}\left(\mathrm{mg} \mathrm{veh}{ }^{-1} \mathrm{~km}^{-1}\right) ; \mathrm{C}_{\text {outlet }}$ and $\mathrm{C}_{\text {inlet }}$ are the specific VOC or $\mathrm{NO}_{2}$ concentrations at TFT-A and TFT-B, respectively, in $\mathrm{mg} \mathrm{m}^{-3}$; $\mathrm{A}$ is the cross-sectional area of the tunnel $\left(50 \mathrm{~m}^{2}\right)$; $\mathrm{U}$ is the hourly average wind speed in the tunnel; $\mathrm{t}$ is the period of sample collection ( $1 \mathrm{~h}=3600 \mathrm{~s})$; $\mathrm{N}$ is the traffic flow in the tunnel; $\mathrm{L}$ is the distance between the two points in the tunnel. It should be noted that if the detection rate of a specific VOC was lower than $30 \%$, it was excluded from the EF calculation. Moreover, the average EF excludes the times when the exhaust-air fans were open.

The types of vehicle that passed through the tunnel were effectively recorded through a fixed camera and counted by the researcher. The emissions of diesel-fuelled vehicles (DVs), gasoline-fuelled vehicles (GVs) and natural gas-fuelled vehicles (CNGVs) were differentiated. In Chengdu, trucks are restricted to entering the city in the daytime [32], therefore the monitoring period can be divided into a period (8:00-14:00) containing all 
types of vehicles and a period (15:00-19:00) containing only non-diesel-fuelled vehicles (NDVs). Then, the relationship among the average EF, the EF of NDVs and the EF of DVs can be explained as follows [31]:

$$
\mathrm{EF}_{\mathrm{veh}}=\mathrm{x} \times \mathrm{EF}_{\mathrm{dv}}+(1-\mathrm{x}) \times \mathrm{EF}_{\mathrm{ndv}}
$$

where $\mathrm{EF}_{\mathrm{veh}}\left(\mathrm{mg} \mathrm{veh}^{-1} \mathrm{~km}^{-1}\right)$ is the average $\mathrm{EF}\left(\mathrm{mg} \mathrm{veh}^{-1} \mathrm{~km}^{-1}\right)$ calculated from the former formula; $\mathrm{EF}_{\mathrm{dv}}\left(\mathrm{mg} \mathrm{veh}^{-1} \mathrm{~km}^{-1}\right)$ is the $\mathrm{EF}$ of the period with DVs passing through the tunnel; $\mathrm{EF}_{\text {ndv }}\left(\mathrm{mg} \mathrm{veh}{ }^{-1} \mathrm{~km}^{-1}\right.$ ) is the average $\mathrm{EF}$ of the period with only NDVs passing through the tunnel; $\mathrm{x}$ is the proportion of diesel vehicles to total vehicles passing through the tunnel. The equation is a straight line whose intercepts at $x=0$ and $x=1$ are $\mathrm{EF}_{\mathrm{dv}}$ and $\mathrm{EF}_{\text {ndv }}$, respectively.

NDVs in Chengdu can be subdivided into CNGVs and GVs. Buses and taxis are two main types of CNGV that pass through the tunnel constantly. Based on the estimated $\mathrm{EF}_{\mathrm{ndv}}$, the same methods were applied for the estimation of $\mathrm{EF}_{\mathrm{gv}}$ and $\mathrm{EF}_{\mathrm{cng}}$.

It should be noted that estimation of EFs by vehicle type is merely an attempt in this study. Due to the small sample size, there is an uncertainty, which will be discussed in the planning experiment section.

\subsection{Photochemical Reactivity of Vehicle Exhaust Emissions}

The chemical reactivity of different VOCs in the atmosphere is different, and the contribution of each compound to the generation of ozone and secondary particles is also different. This study used the ozone formation potential (OFP) to characterize the atmospheric chemical reactivity of $\mathrm{VOC}_{\mathrm{i}}$ to further identify key active components.

The OFP $\left(\mathrm{mgO}_{3} \mathrm{veh}^{-1} \mathrm{~km}^{-1}\right)$ represents the greatest contribution of VOCs to $\mathrm{O}_{3}$ production under optimal reaction conditions $[33,34]$. The calculation formula is as follows:

$$
\mathrm{OFP}=[\mathrm{VOC}]_{\mathrm{i}} \times \mathrm{MIR}
$$

where $[\mathrm{VOC}]_{\mathrm{i}}$ is the $\mathrm{EF}(\mathrm{mg})$ of VOC species $\mathrm{i}$ and $\mathrm{MIR}\left(\mathrm{mgO}_{3} \mathrm{~g}^{-1}\right)$ is the maximum incremental reactivity of VOC species i.

\section{Results and Discussion}

\subsection{Traffic Pattern and Concentration of VOCs at the Tianfu Tunnel}

\subsubsection{Characteristics of the Traffic Pattern and $\mathrm{NO}_{2}$ Concentration}

In total, 4457 vehicles went through TFT during the sample period (8:00-20:00), including $1 \%$ DVs, $79 \%$ GVs and $20 \%$ CNGVs. The time series of vehicle numbers is shown in Figure 3. The vehicle numbers during the morning and noon peaks were similar (516 and 570, respectively) and were higher than during the evening peak (415). The wind speed was maintained at a relatively high level $\left(5 \mathrm{~m} \mathrm{~s}^{-1}\right)$ in the morning, excluding the time when the exhaust-air fans were opened, and it decreased with the reduced traffic in the afternoon. An apparent triple-peak pattern was also found for GVs and CNGVs, while the difference between the high and low values of CNGVs was much lower than that of GVs. DVs appeared only from 8:00 to 14:00 due to the restriction of trucks. According to vehicle type and load capacity, trucks in Chengdu are divided into eight categories, namely A1, A2, B1, B2, C1, C2, D and H. Among them, B2 vehicles are diesel trucks with a load of less than five tons, which can pass through the city centre. In addition, the pilot trucks identified as urban joint distribution and main emergency vehicles are not included in the restricted list. Therefore, DVs were still observed in the daytime [32]. 


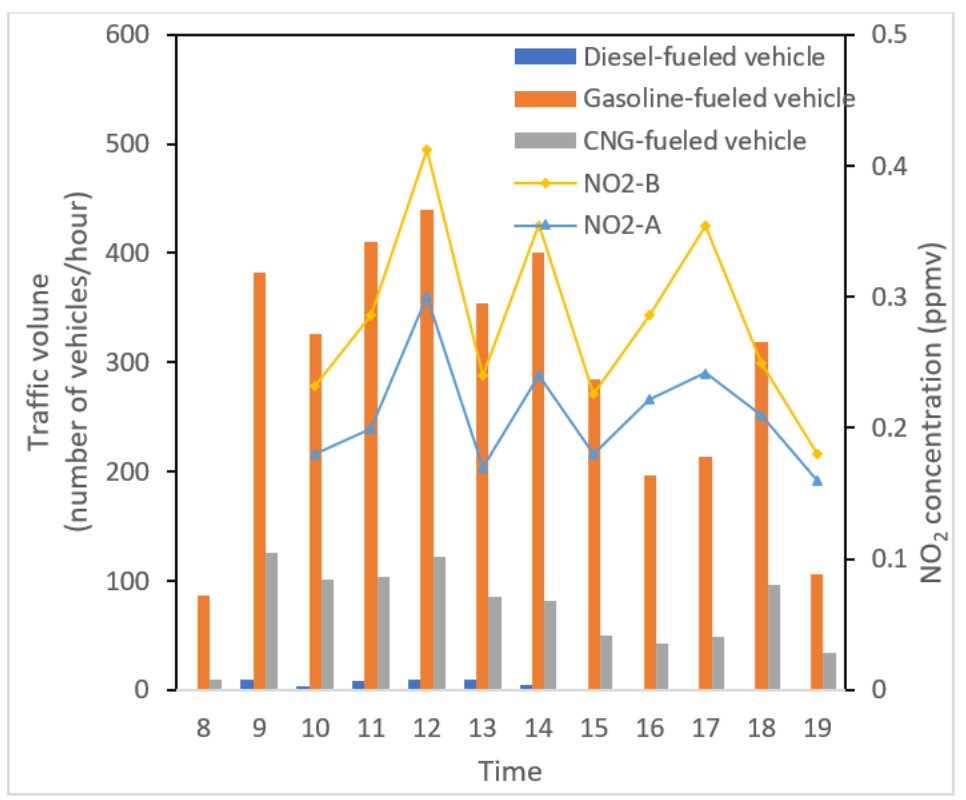

Figure 3. Time series of the numbers of three types of vehicles passing through the tunnel and $\mathrm{NO}_{2}$ concentrations at the inlet $\left(\mathrm{NO}_{2}-\mathrm{A}\right)$ and outlet $\left(\mathrm{NO}_{2}-\mathrm{B}\right)$ of the Tianfu tunnel (TFT).

The average $\mathrm{NO}_{2}$ concentrations at TFT-A and TFT-B were $0.21 \mathrm{ppmv}$ and $0.28 \mathrm{ppmv}$, respectively. The temporal pattern was similar to that of traffic flow; however, the fluctuations in $\mathrm{NO}_{2}$ concentration were sharper. Moreover, the influence of the exhaust-air fans can be illustrated from the observation that the traffic flow in the morning and evening was relatively large whilr the concentration of $\mathrm{NO}_{2}$ was low.

\subsubsection{Concentration of VOCs}

In this study, a total of 50 species were quantified in the samples collected at TFT-A and TFT-B. These species included 19 alkanes, 9 alkenes, 10 aromatics, 1 alkyne, 5 chlorocarbons and 6 OVOCs. For both TFT-A and TFT-B, alkanes were the most abundant group, with percentages of $59 \%$ and $55 \%$, respectively. This group was followed by alkenes $(11 \%)$, aromatic hydrocarbons $(10 \%)$, OVOCs $(10 \%)$, alkynes $(5 \%)$ and chlorocarbons $(5 \%)$ at TFT-A. For TFT-B, higher percentages of alkenes (13\%) and aromatic hydrocarbons $(12 \%)$ were measured.

The total measured VOC (TVOC) concentrations at TFT-A and TFT-B were $138.70 \mathrm{ppbv}$ and $125.93 \mathrm{ppbv}$, respectively. The relatively high concentration of TFT-A was mainly due to the high concentrations of styrene, ethylbenzene, $\mathrm{m}, \mathrm{p}$-xylene, o-xylene, etc., at 8:00. Some studies have found that species such as styrene, ethylbenzene, $\mathrm{m}, \mathrm{p}$-xylene and o-xylene are mainly related to emissions from solvent use [35,36], which indicates that the relatively high values at TFT-A at 8:00 can be attributed to contamination by sources in addition to traffic emission. To eliminate this possible contamination, the 8:00 TFT-A sample was not included in subsequent calculations.

The average concentrations and standard deviations of VOCs at TFT-A and TFT-B are illustrated in Table 2. Ethane and iso-pentane were the most abundant species at both sites, with values of $18.75 \pm 8.46 \mathrm{ppbv}$ and $6.90 \pm 6.40 \mathrm{ppbv}$, respectively, at TFT-A and $29.80 \pm 15.58 \mathrm{ppbv}$ and $13.42 \pm 7.20 \mathrm{ppbv}$, respectively, at TFT-B. $n$-Butane and ethylene were the third most abundant species at TFT-A and TFT-B, respectively. It has been reported that concentrations of individual VOCs in tunnels can be 10 times higher than those of the air outside the tunnel and 5-10 times higher than those in ambient air [37,38]. In this study, the concentrations of ethane, iso-pentane and ethylene in TFT were five-seven times higher than those in the Chengdu ambient air, as obtained from online monitoring by the Chengdu Key Laboratory of Atmospheric Research. 
Table 2. Concentrations and emission factors (EFs) of VOCs at the Tianfu tunnel (TFT).

\begin{tabular}{|c|c|c|c|c|}
\hline \multirow{2}{*}{ VOCs } & \multicolumn{3}{|c|}{ Concentration (ppbv) } & \multirow{2}{*}{$\begin{array}{l}\text { Emission Factor } \\
\left(\mathrm{mg} \mathrm{veh}^{-1} \mathrm{~km}^{-1}\right)\end{array}$} \\
\hline & $\mathbf{A}$ & B & B-A & \\
\hline \multicolumn{5}{|l|}{ Alkanes } \\
\hline Ethane & $18.75 \pm 8.46$ & $29.80 \pm 15.58$ & $14.04 \pm 9.86$ & $22.85 \pm 12.79$ \\
\hline Propane & $3.79 \pm 3.58$ & $3.51 \pm 1.66$ & $0.75 \pm 1.03$ & $1.67 \pm 2.33$ \\
\hline iso-Butane & $6.18 \pm 17.07$ & $1.70 \pm 1.60$ & $0.44 \pm 0.52$ & $1.41 \pm 2.02$ \\
\hline n-Butane & $6.83 \pm 12.19$ & $4.54 \pm 3.49$ & $1.18 \pm 1.44$ & $3.14 \pm 2.75$ \\
\hline Cyclopentane & $0.08 \pm 0.27$ & $0.24 \pm 0.43$ & $0.16 \pm 0.37$ & $0.28 \pm 0.58$ \\
\hline n-Pentane & $2.49 \pm 2.44$ & $5.07 \pm 4.34$ & $2.17 \pm 2.93$ & $10.11 \pm 7.26$ \\
\hline iso-Pentane & $6.90 \pm 6.40$ & $13.42 \pm 7.20$ & $4.71 \pm 5.65$ & $18.25 \pm 8.35$ \\
\hline Cyclohexane & $0.30 \pm 0.47$ & $0.22 \pm 0.53$ & $0.10 \pm 0.31$ & $0.45 \pm 1.10$ \\
\hline Methylcyclopentane & $0.41 \pm 0.66$ & $1.04 \pm 1.22$ & $0.70 \pm 0.83$ & $2.41 \pm 2.52$ \\
\hline n-Hexane & $1.73 \pm 0.88$ & $2.94 \pm 1.59$ & $0.96 \pm 0.93$ & $8.17 \pm 4.71$ \\
\hline 2-Methylpentane & $1.36 \pm 1.42$ & $2.18 \pm 2.08$ & $0.92 \pm 1.15$ & $3.52 \pm 3.47$ \\
\hline 3-Methylpentane & $0.68 \pm 0.84$ & $1.19 \pm 1.40$ & $0.67 \pm 0.83$ & $2.31 \pm 2.49$ \\
\hline Methylcyclohexane & $0.17 \pm 0.40$ & $0.50 \pm 0.64$ & $0.41 \pm 0.58$ & $1.30 \pm 1.56$ \\
\hline n-Heptane & $0.14 \pm 0.32$ & $0.52 \pm 0.69$ & $0.45 \pm 0.66$ & $1.45 \pm 1.74$ \\
\hline 2-Methylhexane & $0.21 \pm 0.39$ & $0.52 \pm 0.69$ & $0.37 \pm 0.58$ & $1.14 \pm 1.43$ \\
\hline 3-Methylhexane & $0.16 \pm 0.38$ & $0.59 \pm 0.78$ & $0.50 \pm 0.75$ & $1.55 \pm 1.91$ \\
\hline 2-Methylheptane & $0.04 \pm 0.14$ & $0.06 \pm 0.21$ & $0.02 \pm 0.27$ & $0.13 \pm 0.43$ \\
\hline 3-Methylheptane & $0.10 \pm 0.35$ & $0.19 \pm 0.44$ & $0.09 \pm 0.59$ & $0.51 \pm 1.11$ \\
\hline Undecane & $0.54 \pm 1.28$ & $0.07 \pm 0.23$ & $0.07 \pm 0.23$ & $0.20 \pm 0.63$ \\
\hline \multicolumn{5}{|l|}{ Alkenes } \\
\hline Ethylene & $6.82 \pm 4.40$ & $10.07 \pm 6.42$ & $3.54 \pm 4.01$ & $4.77 \pm 3.43$ \\
\hline Propylene & $1.71 \pm 0.93$ & $2.43 \pm 1.57$ & $0.88 \pm 1.07$ & $1.60 \pm 1.45$ \\
\hline 1,3-Butadiene & $0.14 \pm 0.33$ & $0.48 \pm 0.61$ & $0.41 \pm 0.60$ & $0.71 \pm 0.91$ \\
\hline 1-Butene & $0.08 \pm 0.28$ & $0.55 \pm 0.82$ & $0.55 \pm 0.82$ & $1.62 \pm 3.11$ \\
\hline trans-2-Butene & $0.50 \pm 1.19$ & $1.08 \pm 1.41$ & $0.77 \pm 0.95$ & $1.72 \pm 1.73$ \\
\hline cis-2-Butene & $0.14 \pm 0.50$ & $0.58 \pm 0.79$ & $0.44 \pm 0.58$ & $0.88 \pm 1.06$ \\
\hline Isoprene & $0.17 \pm 0.33$ & $0.23 \pm 0.42$ & $0.05 \pm 0.61$ & $0.40 \pm 0.67$ \\
\hline trans-2-Pentene & $0.16 \pm 0.57$ & $0.71 \pm 0.94$ & $0.55 \pm 0.77$ & $1.28 \pm 1.53$ \\
\hline cis-2-Pentene & $0.06 \pm 0.22$ & $0.22 \pm 0.40$ & $0.15 \pm 0.32$ & $0.33 \pm 0.57$ \\
\hline \multicolumn{5}{|l|}{ Aromatic hydrocarbons } \\
\hline Benzene & $2.60 \pm 2.08$ & $4.56 \pm 3.48$ & $1.98 \pm 2.24$ & $7.53 \pm 3.43$ \\
\hline Toluene & $2.97 \pm 3.01$ & $3.95 \pm 2.55$ & $1.23 \pm 2.18$ & $8.37 \pm 7.28$ \\
\hline Styrene & $0.07 \pm 0.25$ & $0.07 \pm 0.23$ & $0.07 \pm 0.23$ & $0.58 \pm 1.84$ \\
\hline Ethylbenzene & $0.62 \pm 0.54$ & $1.28 \pm 1.13$ & $0.71 \pm 0.85$ & $3.16 \pm 2.58$ \\
\hline m,p-Xylene & $1.41 \pm 0.97$ & $2.24 \pm 1.37$ & $0.69 \pm 1.33$ & $5.03 \pm 6.74$ \\
\hline o-Xylene & $0.76 \pm 0.58$ & $1.49 \pm 1.39$ & $0.87 \pm 1.11$ & $3.61 \pm 3.29$ \\
\hline 1,3,5-Trimethylbenzene & $0.01 \pm 0.10$ & $0.27 \pm 0.51$ & $0.27 \pm 0.51$ & $0.95 \pm 1.60$ \\
\hline 1,2,4-Trimethylbenzene & $0.18 \pm 0.47$ & $0.46 \pm 0.69$ & $0.31 \pm 0.60$ & $2.86 \pm 5.09$ \\
\hline m-Ethyltoluene & $0.18 \pm 0.44$ & $0.67 \pm 0.99$ & $0.61 \pm 0.86$ & $2.63 \pm 3.24$ \\
\hline o-Ethyltoluene & $0.01 \pm 0.13$ & $0.15 \pm 0.34$ & $0.15 \pm 0.34$ & $0.42 \pm 0.91$ \\
\hline \multicolumn{5}{|l|}{ Alkynes } \\
\hline Acetylene & $3.95 \pm 2.54$ & $6.40 \pm 2.82$ & $2.55 \pm 2.55$ & $4.40 \pm 4.67$ \\
\hline \multicolumn{5}{|l|}{ Chlorocarbons } \\
\hline Chloromethane & $1.24 \pm 0.87$ & $0.94 \pm 0.41$ & $0.10 \pm 0.28$ & $0.59 \pm 1.52$ \\
\hline Dichloromethane & $1.81 \pm 1.26$ & $1.72 \pm 0.39$ & $0.29 \pm 0.61$ & $2.77 \pm 5.68$ \\
\hline 1,2-Dichloroethane & $0.69 \pm 0.73$ & $0.73 \pm 0.52$ & $0.17 \pm 0.30$ & $1.33 \pm 2.54$ \\
\hline Dichlorodifluoromethane & $0.24 \pm 0.35$ & $0.13 \pm 0.30$ & $0.07 \pm 0.23$ & $0.15 \pm 0.48$ \\
\hline trans-1,2-Dichloroethylene & $0.03 \pm 0.11$ & $0.06 \pm 0.21$ & $0.06 \pm 0.21$ & $0.27 \pm 0.85$ \\
\hline \multicolumn{5}{|l|}{ OVOCs } \\
\hline Acetone & $2.98 \pm 1.75$ & $6.70 \pm 3.12$ & $4.06 \pm 2.43$ & $15.31 \pm 10.98$ \\
\hline 2-Hexanone & $0.01 \pm 0.12$ & $0.25 \pm 0.46$ & $0.25 \pm 0.46$ & $1.40 \pm 3.00$ \\
\hline Tetrahydrofuran & $0.02 \pm 0.11$ & $0.38 \pm 1.11$ & $0.38 \pm 1.11$ & $3.10 \pm 8.52$ \\
\hline Methyl tert-butyl ether & $2.37 \pm 2.74$ & $4.06 \pm 3.90$ & $1.69 \pm 2.07$ & $6.94 \pm 4.13$ \\
\hline Ethyl acetate & $1.00 \pm 1.51$ & $0.91 \pm 0.89$ & $0.35 \pm 0.53$ & $3.50 \pm 5.59$ \\
\hline Carbon disulfide & $1.91 \pm 3.18$ & $2.42 \pm 3.73$ & $0.59 \pm 1.21$ & $5.93 \pm 11.76$ \\
\hline
\end{tabular}


For the net concentrations (B-A), ethane was still the most abundant species, with a value of $9.42 \pm 10.85$ ppbv, followed by iso-pentane, acetone, ethylene and acetylene. These top five species comprised approximately $54 \%$ of the TVOCs, which indicates that they had the highest emission rates among vehicular emissions. It is interesting that a few studies have reported that automobile exhaust discharges a high concentration of acetone, but acetone was detected in all the tunnel samples in this study and had a stable net concentration, which conforms to the characteristics of emission accumulation. Similar findings were found in subsequent roadside samples, as detailed in Section 3.3.

Figure 4 shows the temporal pattern of VOCs at TFT-B. High TVOC concentrations were found at 12:00 (214.27 ppbv), 14:00 (233.92 ppbv) and 17:00 (226.73 ppbv). Lower TVOC concentrations were found from 9:00 to 10:00 and from 18:00 to 19:00, during the morning and evening traffic flow peaks for Chengdu, and were affected by the opening of exhaust-air fans. This pattern is generally consistent with the traffic pattern and $\mathrm{NO}_{2}$ concentrations. Interestingly, the proportions of alkenes and aromatic hydrocarbons in the afternoon were five percentage points higher than those in the morning. This result could be related to differences in temperature $\left(2^{\circ} \mathrm{C}\right)$ and vehicle types between the morning and afternoon.

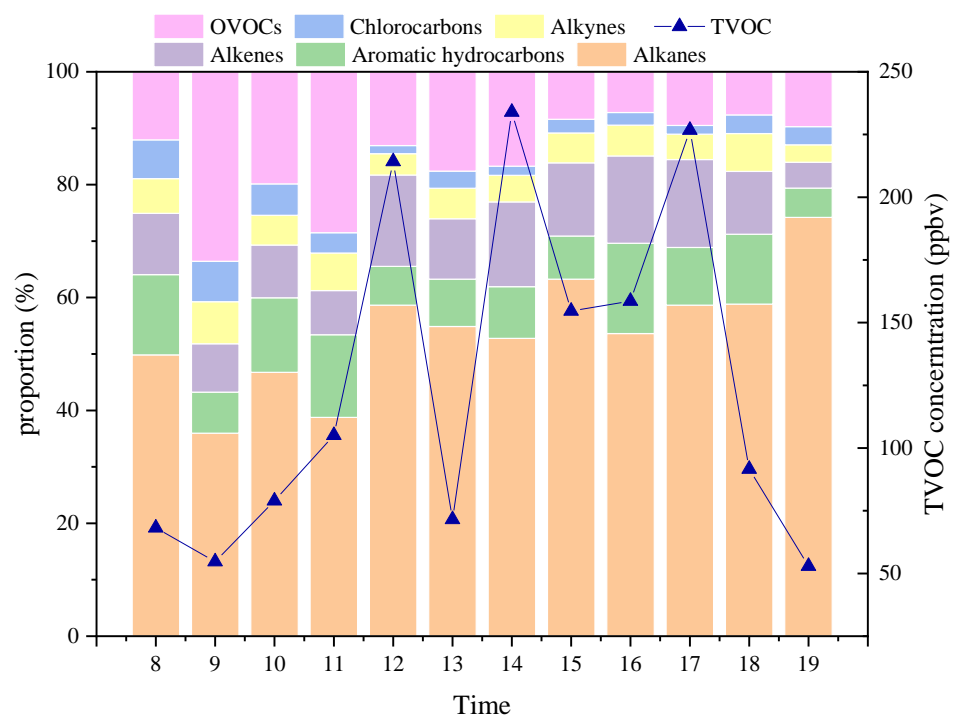

Figure 4. Temporal pattern of VOCs at the outlet of the Tianfu tunnel (TFT-B).

\subsection{Emission Profile and Factors of VOCs at the Tianfu Tunnel}

\subsubsection{General Emission Factors and Emission Factors by Fuel Type}

The general VOC EFs are illustrated in Table 2. The general TVOC EFs ranged from $141.71 \mathrm{mg} \mathrm{veh}^{-1} \mathrm{~km}^{-1}$ to $236.12 \mathrm{mg} \mathrm{veh}^{-1} \mathrm{~km}^{-1}$, and the average was $177.31 \pm 24.59 \mathrm{mg} \mathrm{veh}^{-1} \mathrm{~km}^{-1}$. The five species with the highest EFs were, in decreasing order, ethane (22.85 $\left.\pm 12.79 \mathrm{mg} \mathrm{veh}^{-1} \mathrm{~km}^{-1}\right)$, iso-pentane $\left(18.25 \pm 8.35 \mathrm{mg} \mathrm{veh}^{-1} \mathrm{~km}^{-1}\right)$, acetone $\left(15.31 \pm 10.98 \mathrm{mg} \mathrm{veh}^{-1} \mathrm{~km}^{-1}\right), n$-pentane $\left(10.11 \pm 7.26 \mathrm{mg} \mathrm{veh}^{-1} \mathrm{~km}^{-1}\right)$ and toluene $\left(8.37 \pm 7.28 \mathrm{mg} \mathrm{veh}^{-1} \mathrm{~km}^{-1}\right)$. The five most abundant species contributed over $43 \%$ of TVOC EFs.

Fuel quality and vehicle engine technology could be the two most important factors affecting the VOC EF of the vehicles passing through the tunnel [19]. Comparing the top ten species of EFs from Chengdu and other cities in China [31,39,40], ethane, iso-pentane, ethylene, acetylene and toluene are the most common species, and the EFs of iso-pentane, acetylene and toluene of the TFT tunnel and the Nanjing tunnel were basically the same. However, high EFs of propane and $n$-butane relating to liquefied petroleum gas (LPG) or $\mathrm{CNG}$ emission are not found in all studies. The analytical technology could be one of the 
reasons for the differences and similarities among those studies, as the fuel contaminants and vehicle engine technologies vary in most studies.

The VOC EFs of DVs, GVs and CNGVs were estimated based on linear regression analysis, with values of $272.39 \pm 191.17 \mathrm{mg} \mathrm{veh}^{-1} \mathrm{~km}^{-1}, 185.08 \pm 12.85 \mathrm{mg} \mathrm{veh}^{-1} \mathrm{~km}^{-1}$ and $158.72 \pm 3.21 \mathrm{mg} \mathrm{veh}^{-1} \mathrm{~km}^{-1}$, respectively. It should be noted that the proportion of DVs in the total number of vehicles ranged from $0.82 \%$ to $2.23 \%$, which is too low to obtain an acceptable standard deviation and thus contains considerable uncertainty.

\subsubsection{Photochemical Activity}

The contribution of VOCs from vehicular emissions to OFP was calculated based on the MIR method [33]. The total OFP of measured VOCs was $392.28 \mathrm{mgO}_{3} \mathrm{veh}^{-1} \mathrm{~km}^{-1}$, which was close to the value obtained in a study carried out in Nanjing in 2015 $\left(373.88 \mathrm{mgO}_{3} \mathrm{veh}^{-1} \mathrm{~km}^{-1}\right)$, but much higher than that calculated in a study in Hong Kang in $2015\left(190.80 \mathrm{mgO}_{3} \mathrm{veh}^{-1} \mathrm{~km}^{-1}\right)$. The top 20 species with the highest OFPs are listed in Figure 5. The largest contributors to $\mathrm{O}_{3}$ production were $\mathrm{m}$, $\mathrm{p}$-xylene $\left(44.93 \mathrm{mgO}_{3} \mathrm{veh}^{-1} \mathrm{~km}^{-1}\right)$, ethylene (39.30 $\mathrm{mgO}_{3} \mathrm{veh}^{-1} \mathrm{~km}^{-1}$ ) and toluene (30.73 $\mathrm{mgO}_{3} \mathrm{veh}^{-1} \mathrm{~km}^{-1}$ ), which contributed $11 \%$, $10 \%$ and $8 \%$, respectively. Based on the same calculation method, the major contributors to $\mathrm{O}_{3}$ production from DV, GV and CNGV emissions in the tunnel were determined, among which the largest contributors were ethylene $\left(45.32 \mathrm{mgO}_{3} \mathrm{veh}^{-1} \mathrm{~km}^{-1}\right), \mathrm{m}$, p-xylene (46.34 $\mathrm{mgO}_{3} \mathrm{veh}^{-1} \mathrm{~km}^{-1}$ ) and trans-2-butene $\left(33.23 \mathrm{mgO}_{3} \mathrm{veh}^{-1} \mathrm{~km}^{-1}\right.$ ), respectively.

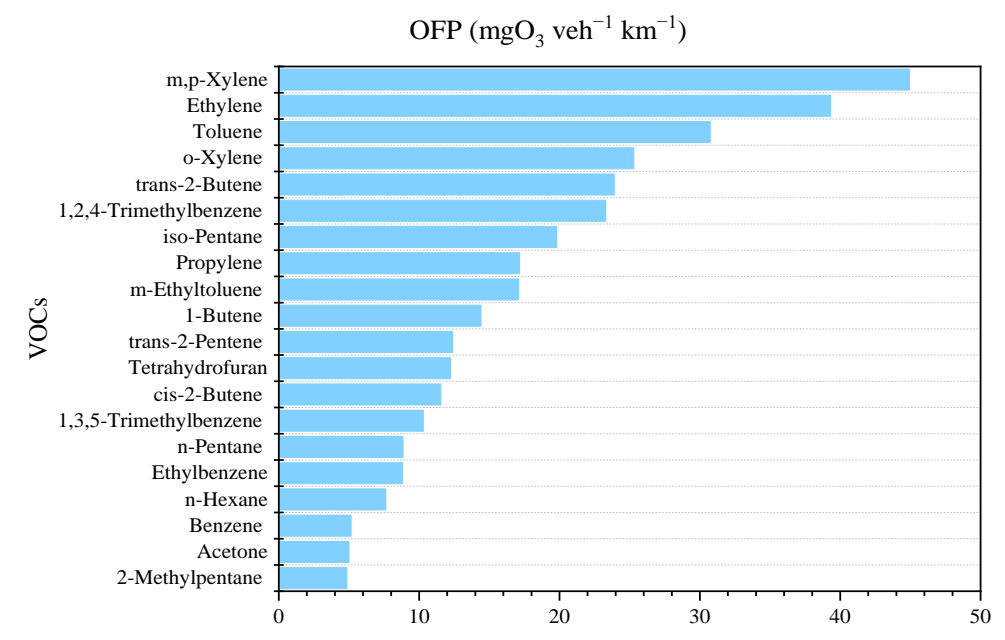

Figure 5. Top 20 species with the highest OFP from vehicular emissions.

\subsection{Characteristics of Road Environment VOCs}

A total of 50,33 and 73 species of VOCs were determined in the roadside atmosphere samples of FLR, HGA and RSR, respectively. Twenty-nine of these compounds were quantified at all three sample sites, including 11 alkanes, 5 aromatics, 5 chlorocarbons and 3 alkenes. All of the species were also measured in the tunnel samples, except for tetrachloroethylene. Figure 6 illustrates the average concentrations of measured VOCs at FLR, HGA, RSR and TFT. The TVOC concentrations at FLR, HGA and RSR were $61.85 \pm 47.90 \mathrm{ppbv}, 64.57 \pm 28.91 \mathrm{ppbv}$ and $175.65 \pm 74.83$ ppbv, respectively. This concentration sequence was the same as the sequence of traffic flow. The concentration at RSR was higher than that at TFT, and the difference mainly came from alkanes, aromatic hydrocarbons and aldehydes. It is interesting that the concentration of OVOCs at HGA was close to those at RSR and TFT, however the TVOC concentration was lower, which resulted in a high contribution (23\%) of OVOCs at HGA. Among the OVOCs at HGA, relatively high concentrations of ethyl acetate and methyl tert-butyl ether were the main contributors. A preliminary speculation is that these compounds came from lubricants or solvents used by small motorcycle repair shops near the observation point at HGA. 

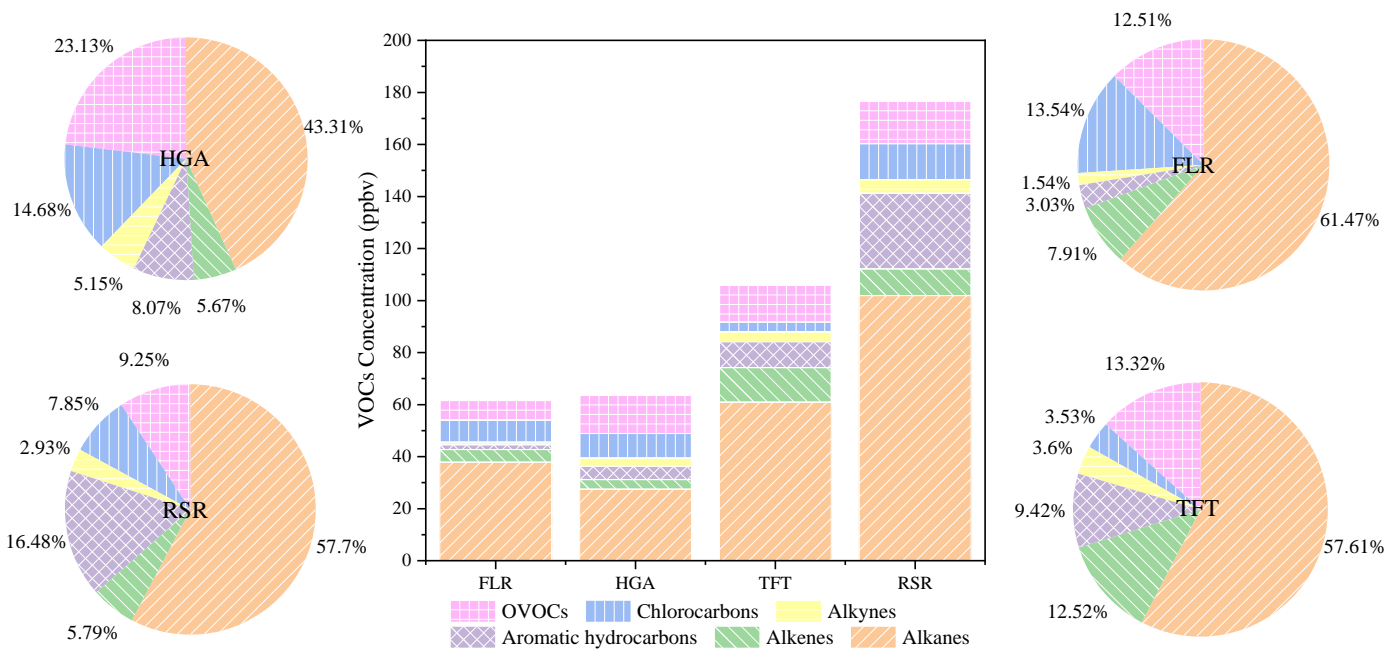

Figure 6. VOC concentrations and their group compositions at Fanglin Road (FLR), Hongguang Avenue (HGA), Tianfu tunnel (TFT) and Renmin South Road (RSR).

Most of the compounds measured in the tunnel were also observed in the roadside environment. Among the measured VOCs at the roadsides, iso-pentane was the most abundant compound for the three roads and was the second most abundant compound in the tunnel. The average concentrations of iso-pentane at FLR, HGA and RSR were $23.89 \pm 12.58 \mathrm{ppbv}, 12.76 \pm 16.93 \mathrm{ppbv}$ and $44.75 \pm 7.63 \mathrm{ppbv}$, respectively. The values of iso-pentane at RSR and FLR were two-six times higher than that in the tunnel. Moreover, the concentrations of iso-butane at these two points were also significantly higher than that of the tunnel. Considering that iso-pentane and iso-butane are two of the most abundant compounds in gasoline evaporation emissions $[36,41]$ and the samples were taken on a summer day with daily temperatures above $33^{\circ} \mathrm{C}$, the high concentrations of iso-pentane and iso-butane at the roadsides have a certain correlation with the high emission of gasoline evaporation in the open environment. The most abundant compound in the tunnel sample was ethane, which was the second most abundant compound at FLR and HGA, and the fifth most abundant compound at RSR. Moreover, a high concentration of acetone was also found in more than $70 \%$ of the samples at the roadsides, and the concentrations were in the range of 1.42-18.74 ppbv. The concentrations at FLR and HGA were similar and were significantly lower than that at RSR, which has significantly higher traffic flow. Acetone was found in both tunnel and roadside samples with reliable values and is believed to be associated with fuel combustion in this study.

Due to the activity differences among VOC species, the ratio of specific VOCs varies greatly among different sources and atmospheric environments. In this study, the ratios of propane/isobutane (P/IB), m,p-xylene/ethylbenzene (M,P/EB) and toluene/benzene (T/B) were used to compare the roads and tunnel, as illustrated in Table 3. The ratios of P/IB at the three roadside sites were close, in the range of 1.68-2.14. These values were also very close to the ratio at TFT (1.81) and the emission ratios of GVs (0.74) [35]. The M,P/EB ratio has been extensively applied as an indicator of photochemical reaction processes $[42,43]$ since ethylbenzene reacts more slowly with hydroxyl radicals $(\mathrm{OH})$ than with $\mathrm{m}, \mathrm{p}$-xylene; thus, the $\mathrm{M}, \mathrm{P} / \mathrm{EB}$ ratio decreases as photochemical reactions occur. The $\mathrm{M}, \mathrm{P} / \mathrm{EB}$ ratio at TFT was close to the ratio in the tunnel of Nanjing, Hong Kong and Guangzhou [31,39,40], and these values were higher than those of roadside samples. This result indicates that the tunnel air mass was less affected than the roadside air by photochemical production [44]. The T/B ratio at RSR was much higher than that at TFT, but close to the ratio in the tunnel of Hong Kong (2015) [39]. This result could be due to the combined impact of the high emission of toluene from fuel evaporation and solvent use. The ratio at TFT was close to the ratio in the tunnel of Nanjing and Hong Kong (2003), but much lower than that of 
Hong Kong (2015) [39]. The increase in the T/B ratio between 2003 and 2015 in Hong Kong was the result of vehicular emission reduction strategies undertaken by the government of Hong Kong. This change in ratio suggests that Chengdu has plenty of room for vehicle emission reduction and that much can be learned from the actions taken by Hong Kong.

Table 3. The ratios of propane/isobutane (P/IB), m,p-xylene/ethylbenzene (M,P/EB) and toluene/benzene (T/B) at Fanglin Road (FLR), Hongguang Avenue (HGA), Tianfu tunnel (TFT) and Renmin South Road (RSR), as well as other Chinese cities.

\begin{tabular}{cccc}
\hline & P/IB & M,P/EB & T/B \\
\hline Chengdu Roadsides: FLR (This study) & 2.14 & 1.86 & 1.84 \\
Chengdu Roadsides: HGA (This study) & 1.68 & 2.17 & 3.48 \\
Chengdu Roadsides: RSR (This study) & 2.04 & 1.41 & 5.37 \\
Chengdu Tunnel: TFT (This study) & 1.81 & 2.93 & 1.68 \\
Nanjing Tunnel [31] & 5.21 & 2.39 & 1.83 \\
Nanjing Roadsides [44] & $/$ & 1.17 & 3.09 \\
Hong Kong Tunnel: 2015 [39] & 1.05 & 2.44 & 5.59 \\
HongKong Tunnel: 2003 [39] & 1.41 & 2.79 & 2.27 \\
\hline
\end{tabular}

\section{Conclusions}

A total of 50 species of VOCs were quantified in the tunnel, with 4457 vehicles passing through during the sampling period. The TVOC concentration in TFT was in the range of 61.53-233.92 ppbv. The average TVOC concentration was $88.57 \mathrm{ppbv}$ and $125.93 \mathrm{pptv}$ at TFT-A and TFT-B, respectively, after eliminating possible contamination at 8:00 at TFT-A. Alkanes were the most abundant group, followed by alkenes, aromatic hydrocarbons, OVOCs, alkynes and chlorocarbons. The temporal patterns of the concentrations of TVOC and $\mathrm{NO}_{2}$ were generally consistent with the traffic flow, except for the times when the exhaust-air fans were open.

The general TVOC EFs ranged from $141.71 \mathrm{mg} \mathrm{veh}^{-1} \mathrm{~km}^{-1}$ to $236.12 \mathrm{mg} \mathrm{veh}^{-1} \mathrm{~km}^{-1}$, and the average was $177.31 \pm 24.59 \mathrm{mg} \mathrm{veh}^{-1} \mathrm{~km}^{-1}$. The five most abundant species were ethane, iso-pentane, acetone, $n$-pentane and toluene, which contributed over $43 \%$ of TVOC. The TVOC EFs of DVs, GVs and CNGVs were estimated based on linear regression analysis, with values of $272.39 \pm 191.17 \mathrm{mg} \mathrm{veh}^{-1} \mathrm{~km}^{-1}, 185.08 \pm 12.85 \mathrm{mg} \mathrm{veh}^{-1} \mathrm{~km}^{-1}$ and $158.72 \pm 3.21 \mathrm{mg} \mathrm{veh}^{-1} \mathrm{~km}^{-1}$, respectively.

Samples collected from three the contrasting roadside locations were found to contain 50,33 and 73 species of VOCs. Their concentrations were $61.85 \pm 47.90$ ppbv (FLR), $64.57 \pm 28.91 \mathrm{ppbv}$ (HGA) and $175.65 \pm 74.83 \mathrm{ppbv}$ (RSR), and the sequence was the same as the sequence of traffic flow. Most of the traffic-related compounds were observed in the roadside environment in this study. Higher concentrations of iso-pentane and isobutane were observed in the roadside samples than in the tunnel samples, indicating a high contribution of gasoline evaporation emissions in Chengdu. In further analysis, the ratios of $\mathrm{P} / \mathrm{IB}, \mathrm{M}, \mathrm{P} / \mathrm{EB}$ and $\mathrm{T} / \mathrm{B}$ were used to compare the roads and tunnel, as were results from other studies. The ambient air of roadsides in Chengdu has significant vehicle emission characteristics, which are closely related to source emissions. Comparing the vehicle emissions with those of other cities, there is room for further reductions in vehicle emissions.

Supplementary Materials: The following are available online at https:/ / www.mdpi.com/article / $10.3390 /$ atmos12070861/s1.

Author Contributions: Conceptualization, X.Z. and M.F.; methodology, M.F.; validation, L.Z.; formal analysis, M.F.; investigation, T.Z. and Z.Z.; resources, M.F. and Q.T.; data curation, X.H.; writingOriginal draft preparation, M.F.; writing-Review and editing, M.F., L.Z. and C.H.; visualization, Y.D. and D.S.; supervision, C.H.; project administration and funding acquisition, M.F. All authors have read and agreed to the published version of the manuscript. 
Funding: This work was supported by the National Natural Science Foundation of China (No. 4187050405) and the Ministry of Science and Technology of the People's Republic of China (No. 2018YFC0214001).

Institutional Review Board Statement: Not applicable.

Informed Consent Statement: Not applicable.

Data Availability Statement: Data is contained within this article and Supplementary Material.

Acknowledgments: Thanks to all interns for participating in the sample collection work, and thanks to other colleagues in the project team for all kinds of support.

Conflicts of Interest: On behalf all co-authors, we would like to contribute the manuscript entitled Real-world vehicle volatile organic compound emissions and their source profile in Chengdu based on a roadside and tunnel study for consideration of publication in Atmosphere. We declare that submitted manuscript does not contain previously published material and are not under consideration for publication elsewhere. Each author has made an important scientific contribution to the study and is thoroughly familiar with the primary data. All authors listed have read the complete manuscript and have approved submission of the paper. The manuscript is truthful original work without fabrication, fraud or plagiarism. All authors declare that there are no conflicts of interest. Relate the study to previously published work: None. The type of article: Monitoring experiment. Prior interactions with Atmosphere regarding the submitted manuscript: None.

\section{References}

1. Rohde, R.A.; Muller, R.A. Air Pollution in China: Mapping of Concentrations and Sources. PLoS ONE 2015, 10, e0135749. [CrossRef]

2. He, K.; Hong Huo, A.; Zhang, Q. Urban Air Pollution in China: Current Status, Characteristics, and Progress. Annu. Rev. Energy Environ. 2011, 27, 397-431. [CrossRef]

3. Chan, C.K.; Yao, X. Air Pollution in Megacities in China. Atmos. Environ. 2008, 42, 1-42. [CrossRef]

4. Feng, Y.; Ning, M.; Lei, Y.; Sun, Y.; Liu, W.; Wang, J. Defending blue sky in China: Effectiveness of the "Air Pollution Prevention and Control Action Plan" on air quality improvements from 2013 to 2017. J. Environ. Manag. 2019, 252, 109603. [CrossRef]

5. Wang, Y.; Guo, H.; Lyu, X.; Zhang, L.; Zeren, Y.; Zou, S.; Ling, Z. Photochemical evolution of continental air masses and their influence on ozone formation over the South China Sea. Sci. Total Environ. 2019, 673, 424-434. [CrossRef] [PubMed]

6. Zhang, X.; Xue, Z.; Li, H.; Yan, L.; Yang, Y.; Wang, Y.; Duan, J.; Li, L.; Chai, F.; Cheng, M.; et al. Ambient volatile organic compounds pollution in China. J. Environ. Sci. 2017, 55, 69-75. [CrossRef]

7. Wu, R.; Li, J.; Hao, Y.; Li, Y.; Zeng, L.; Xie, S. Evolution process and sources of ambient volatile organic compounds during a severe haze event in Beijing, China. Sci. Total Environ. 2016, 560-561, 62-72. [CrossRef] [PubMed]

8. Watson, J.G.; Chow, J.C.; Fujita, E.M. Review of volatile organic compound source apportionment by chemical mass balance. Atmos. Environ. 2001, 35, 1567-1584. [CrossRef]

9. Atkinson, R.; Arey, J. Atmospheric Degradation of Volatile Organic Compounds. Chem. Rev. 2003, 103, 4605. [CrossRef] [PubMed]

10. Mo, Z.; Shao, M.; Lu, S.; Niu, H.; Zhou, M.; Sun, J. Characterization of non-methane hydrocarbons and their sources in an industrialized coastal city, Yangtze River Delta, China. Sci. Total Environ. 2017, 593-594, 641. [CrossRef]

11. Duan, J.; Tan, J.; Yang, L.; Wu, S.; Hao, J. Concentration, sources and ozone formation potential of volatile organic compounds (VOCs) during ozone episode in Beijing. Atmos. Res. 2008, 88, 25-35. [CrossRef]

12. Song, M.; Tan, Q.; Feng, M.; Qu, Y.; Liu, X.; An, J.; Zhang, Y. Source Apportionment and Secondary Transformation of Atmospheric Nonmethane Hydrocarbons in Chengdu, Southwest China. J. Geophys. Res. Atmos. 2018, 123, 9741-9763. [CrossRef]

13. Charron, A.; Polo-Rehn, L.; Besombes, J.-L.; Golly, B.; Jaffrezo, J.-L. Identification and quantification of particulate tracers of exhaust and non-exhaust vehicle emissions. Atmos. Chem. Phys. 2019, 19, 5187-5207. [CrossRef]

14. Hao, Y.; Gao, C.; Deng, S.; Yuan, M.; Song, W.; Lu, Z.; Qiu, Z. Chemical characterisation of PM2.5 emitted from motor vehicles powered by diesel, gasoline, natural gas and methanol fuel. Sci. Total Environ. 2019, 674, 128-139. [CrossRef] [PubMed]

15. Zardini, A.A.; Platt, S.M.; Clairotte, M.; El Haddad, I.; Temime-Roussel, B.; Marchand, N.; JežEk, I.; Drinovec, L.; Močnik, G.A.; Slowik, J.G. Effects of alkylate fuel on exhaust emissions and secondary aerosol formation of a 2-stroke and a 4-stroke scooter. Atmos. Environ. 2014, 94, 307-315. [CrossRef]

16. Li, K.; Chen, L.; Han, K.; Lv, B.; Bao, K.; Wu, X.; Gao, X.; Cen, K. Smog chamber study on aging of combustion soot in isoprene/SO2/ NOx system: Changes of mass, size, effective density, morphology and mixing state. Atmos. Res. 2017, 184, 139-148. [CrossRef]

17. Colberg, C.; Tona, B.; Stahel, W.; Meier, M.; Staehelin, J. Comparison of a road traffic emission model (HBEFA) with emissions derived from measurements in the Gubrist road tunnel, Switzerland. Atmos. Environ. 2005, 39, 4703-4714. [CrossRef]

18. Hung-Lung, C.; Ching-Shyung, H.; Chen, S.Y.; Wu, M.C.; Ma, S.Y.; Huang, Y.S. Emission factors and characteristics of criteria pollutants and volatile organic compounds (VOCs) in a freeway tunnel study. Sci. Total Environ. 2007, 381, 200-211. [CrossRef] [PubMed] 
19. Ho, K.F.; Ho, S.S.H.; Cheng, Y.; Lee, S.C.; Yu, J.Z. Real-world emission factors of fifteen carbonyl compounds measured in a Hong Kong tunnel. Atmos. Environ. 2007, 41, 1747-1758. [CrossRef]

20. Pierson, W.R.; Gertler, A.W.; Robinson, N.F.; Sagebiel, J.C.; Zielinska, B.; Bishop, G.A.; Stedman, D.H.; Zweidinger, R.B.; Ray, W.D. Real-world automotive emissions-Summary of studies in the Fort McHenry and Tuscarora mountain tunnels. Atmos. Environ. 1996, 30, 2233-2256. [CrossRef]

21. Ban-Weiss, G.A.; McLaughlin, J.P.; Harley, R.A.; Kean, A.J.; Grosjean, E.; Grosjean, D. Carbonyl and nitrogen dioxide emissions from gasoline- and diesel-powered motor vehicles. Environ. Sci. Technol. 2008, 42, 3944. [CrossRef]

22. Johnson, K.C.; Durbin, T.D.; Cocker, D.R., III; Miller, W.J.; Bishnu, D.K.; Maldonado, H.; Moynahan, N.; Ensfield, C.; Laroo, C.A. On-road comparison of a portable emission measurement system with a mobile reference laboratory for a heavy-duty diesel vehicle. Atmos. Environ. 2009, 43, 2877-2883. [CrossRef]

23. Liu, T.; Wang, X.; Wang, B.; Ding, X.; Deng, W.; Lü, S.; Zhang, Y. Emission factor of ammonia (NH3) from on-road vehicles in China: Tunnel tests in urban Guangzhou. Environ. Res. Lett. 2014, 9, 064027. [CrossRef]

24. Xiao, F.; Wang, S.; Zhao, B.; Jia, X.; Hao, J. Emission inventory of primary pollutants and chemical speciation in 2010 for the Yangtze River Delta region, China. Atmos. Environ. 2013, 70, 39-50.

25. Lang, J.; Cheng, S.; Wei, W.; Zhou, Y.; Wei, X.; Chen, D. A study on the trends of vehicular emissions in the Beijing-Tianjin-Hebei (BTH) region, China. Atmos. Environ. 2012, 62, 605-614. [CrossRef]

26. Souhu. Chengdu Ranks the Second in Terms of Vehicle Ownership in China (In Chinese). Available online: https://www.sohu. com/a/218260672_400718 (accessed on 29 May 2020).

27. Tan, Z.; Lu, K.; Jiang, M.; Su, R.; Dong, H.; Zeng, L.; Xie, S.; Tan, Q.; Zhang, Y. Exploring ozone pollution in Chengdu, southwestern China: A case study from radical chemistry to O3-VOC-NOx sensitivity. Sci. Total Environ. 2018, 636, 775-786. [CrossRef]

28. U.S. Environmental Protection Agency. USEPA Method TO-15 Volatile Organic Compounds. In Compendium of Methods for the Determination of Toxic Organic Compounds in Ambient Air; U.S. Environmental Protection Agency: Washington, DC, USA, 1999; Volume EPA/625/R-96/010b.

29. Ministry of Environmental Protection. Ambient air-Determination of volatile organic compounds-Collected by specially prepared canisters and analyzed by gas chromatography/mass spectrometry. In National Environmental Protection Standard of The People's Republic Of China; Ministry of Environmental Protection: Beijing, China, 2015; Volume HJ 759-2015.

30. Ministry of Environmental Protection. Air Quality-Determination of Aniline-N-(1-Naphthyl) Ethylene Diamine Dihydrochloride Spectrophotometric Method; Ministry of Environmental Protection: Beijing, China, 1995; Volume GB/T 15502-1995.

31. Zhang, Q.; Wu, L.; Fang, X.; Liu, M.; Mao, H. Emission factors of volatile organic compounds (VOCs) based on the detailed vehicle classification in a tunnel study. Sci. Total Environ. 2017, 624, 878. [CrossRef]

32. Chengdu Public Security Bureau. Notice on the Management of Urban Road License for Freight Cars in 2017. Available online: http:/ /gk.chengdu.gov.cn/govInfoPub/detail.action?id=84998\&tn=6 (accessed on 29 May 2020).

33. Carter, W.P.L. Development of Ozone Reactivity Scales for Volatile Organic Compounds. J. Air Waste Manag. Assoc. 1994, 44, 881-899. [CrossRef]

34. Carter, W.P.L.; Seinfeld, J.H. Winter ozone formation and VOC incremental reactivities in the Upper Green River Basin of Wyoming. Atmos. Environ. 2012, 50, 255-266. [CrossRef]

35. Liu, Y.; Shao, M.; Fu, L.; Lu, S.; Zeng, L.; Tang, D. Source profiles of volatile organic compounds (VOCs) measured in China: Part I. Atmos. Environ. 2008, 42, 6247-6260. [CrossRef]

36. Mo, Z.; Shao, M.; Lu, S. Compilation of a source profile database for hydrocarbon and OVOC emissions in China. Atmos. Environ. 2016, 143, 209-217. [CrossRef]

37. Kirchstetter, T.W.; Singer, B.C.; Harley, R.A.; Kendall, G.R.; Chan, W. Impact of oxygenated gasoline use on motor vehicle emissions. Environ. Sci. Technol. 1996, 30, 661-670. [CrossRef]

38. Ho, K.F.; Ho, S.S.H.; Lee, S.C.; Cheng, Y.; Chow, J.C.; Watson, J.G.; Louie, P.K.K.; Tian, L. Emissions of gas- and particle-phase polycyclic aromatic hydrocarbons (PAHs) in the Shing Mun Tunnel, Hong Kong. Atmos. Environ. 2009, 43, 6343-6351. [CrossRef]

39. Cui, L.; Wang, X.L.; Ho, K.F.; Gao, Y.; Liu, C.; Ho, S.S.H.; Li, H.W.; Lee, S.C.; Wang, X.M.; Jiang, B.Q.; et al. Decrease of VOC emissions from vehicular emissions in Hong Kong from 2003 to 2015: Results from a tunnel study. Atmos. Environ. 2018, 177, 64-74. [CrossRef]

40. Zhang, Y.; Yang, W.; Simpson, I.; Huang, X.; Yu, J.; Huang, Z.; Wang, Z.; Zhang, Z.; Liu, D.; Huang, Z.; et al. Decadal changes in emissions of volatile organic compounds (VOCs) from on-road vehicles with intensified automobile pollution control: Case study in a busy urban tunnel in south China. Environ. Pollut. 2018, 233, 806-819. [CrossRef] [PubMed]

41. Dai, P.; Ge, Y.; Lin, Y.; Su, S.; Liang, B. Investigation on characteristics of exhaust and evaporative emissions from passenger cars fueled with gasoline/methanol blends. Fuel 2013, 113, 10-16. [CrossRef]

42. Nelson, P.F.; Quigley, S.M. The m,p-xylenes:ethylbenzene ratio. A technique for estimating hydrocarbon age in ambient atmospheres. Atmos. Environ. 1983, 17, 659-662. [CrossRef]

43. Shiu, C.J.; Liu, S.C.; Chang, C.C.; Chen, J.P.; Chou, C.C.K.; Lin, C.Y.; Young, C.Y. Photochemical production of ozone and control strategy for Southern Taiwan. Atmos. Environ. 2007, 41, 9324-9340. [CrossRef]

44. Wang, P.; Zhao, W. Assessment of ambient volatile organic compounds (VOCs) near major roads in urban Nanjing, China. Atmos. Res. 2008, 89, 289-297. [CrossRef] 